Ramiro, Enric (coord.) (2019). Dones científiques: 50 segles de desigualtat. Alzira: Reclam editorial, 4 a edició.

Ramiro, Enric i Prades, Sara (2019). África, tan a prop i tan lluny. Universitat Jaume I: Castelló, za edició.

Víctor Grau

Universitat Rovira i Virgili

\title{
Fem de la història un joc de cartes!
}

Tradicionalment s'ha pensat que no és compatible jugar i aprendre a la vegada. Darrerament, però, ha sorgit un corrent creixent de docents que sosté que el joc i l'activitat lúdica són una eina molt valuosa per ensenyar (Gilabert, 2017). El joc, més enllà d'estar associat al plaer, pot esdevenir un facilitador de l'aprenentatge (Marín i Hierro, 2017) i, sobretot, facilita la predisposició de la persona a atendre un nou missatge.

Enric Ramiro, professor de Didàctica de les Ciències Socials del Departament d'Educació de la Universitat Jaume I, ja fa temps que proposa una didàctica diferent i vivencial que permet despertar l'interès dels alumnes per la ciència. És més, ho creu fermament (Tomàs, 2017): «el joc és la manera de fer facil allò difícil». El creador de La maleta de la ciència (2013) i promotor de la matemàgia s'ha enrolat en un nou projecte que ha acabat amb l'elaboració de dues baralles de cartes franceses. La primera pretén promoure el coneixement de la història de l'Àfrica, i la segona, fer visible el paper de les dones en el camp científic o intellectual al llarg del temps. Juntament amb altres collegues vinculats als grup de recerca DIMPA (Didàctica de la Imatge i el Patrimoni), ha aconseguit presentar una brillant adaptació didàctica sorgida d'una pro- 
funda revisió bibliogràfica. Dues baralles de cartes educatives dirigides al públic en general amb un objectius compartit: apropar continguts que a priori poden semblar difícils d'assumir o fins i tot poc atractius. Cada carta és una invitació a la recerca.

\section{Àfrica, tan a prop i tan lluny}

Aquesta baralla de cartes està conformada per cinquanta-dos personatges rellevants, d'àmbits diversos i de totes les grans regions africanes des del quart millenni aC. Dos pals d'homes i dos de dones que permeten fer un recorregut al llarg de la història de l'Àfrica. Es destaquen personatges tan antics com Nefertiti, reina de Núbia, o de vigent actualitat com Samuel Eto'o, exjugador de futbol d'equips tan importants com el FC Barcelona. Tal com indica el mateix autor (Llorens, 2017), «l'Àfrica no és sinònim de guerra, fam i misèria, sinó un continent amb sis millennis d'història desconeguda, molts cops mal interpre-

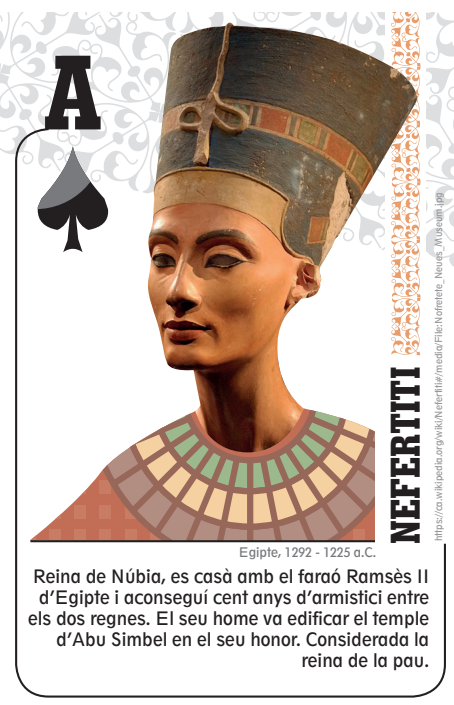
tada, tergiversada $\mathrm{i}$ invisible».

\section{Ciència en femení plural}

En aquesta ocasió, cada carta representa la figura d'una dona amb alguns apunts sobre la seva vida i miracles. Una relació de cinquanta-dues dones que han destacat en camps intellectuals diversos al llarg del temps; importants com ara Merit Ptah (del s. xxviI aC), la primera dona esmentada en la història de la ciència, o Enheduana, primera persona que va signar un poema i que a més era astrònoma i conjugava ciència i lletres. Tal com indica l'autor (Tomàs, 2017), «la història de la ciència no es pot fer sense el paper de les dones, tot i que la majoria hagin passat a l'oblit, s'hagin in- 
tentat silenciar o fins i tot esborrar de la mateixa història». Aquesta baralla de cartes és el resultat de deu anys de recerca dedicada a la recuperació de la tasca de dones científiques des del segle xxvin aC.

Aquests dos recursos didàctics, més enllà de la seva aportació formativa, són una prova més que l'estudi històric pot acabar més enllà d'un manual, un pòster o un llibre de divulgació; també un joc, com a recurs didàctic. Si començàvem afirmant que jugar i aprendre són compatibles, tanquem afirmant que la investigació historiogràfica i la producció didàctica també ho són.

\section{Referències bibliogràfiques}

Gilabert, T. (8 abril 2017). «Fem de la classe un joc?». Ara Criatures.

LLORENS, D. (4 gener 2017). «La UJI crea una baraja didáctica sobre África». El Periódico Mediterráneo.

Marín, I.; Hierro, E. (2017). «El joc, al cor del procés d'ensenyament i aprenentatge». Guix. Elements d'Acció Educativa, 432.

RAmiro, E. (2010). La maleta de la ciencia: 60 experiments d'aire i agua i centenars de recursos per a tots. Barcelona: Graó.

Tomàs, M. (18 març 2017). «L'espurna de la vida, en femení». Levante. El Mercantil Valenciano, 70. 